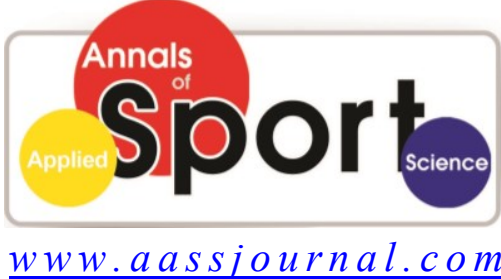

ISS N (Online): $2322-4479$

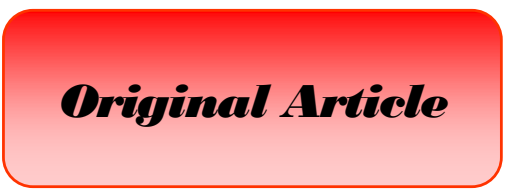

Received: $29 / 04 / 2014$ Accepted: 07/07/2014

\title{
The Managerial Roles of Sports Clubs CEOs in the Current and Desirable Conditions
}

\section{${ }^{1}$ Mahboobeh Surani*, ${ }^{1}$ Rahim Ramezaninezhad, ${ }^{1}$ Noshin Benar, ${ }^{1}$ Hamidreza Goharrostami}

1. Department of Sports Management, Faculty of Physical Education and Sports Sciences, University of Guilan, Rasht, Iran.

\begin{abstract}
Today, the proper playing of managerial roles is of special importance in effective and successful management of sports clubs. The present paper aimed to study the managerial roles of sports clubs CEOs in Isfahan Province in the current and desirable conditions. Statistical population included all managers and directors of Sepahan, Zobahan, Foolad Mahan, and Gitipasand sports clubs (N=83), which was considered as the sample as well. An author-made questionnaire with 31 items on a Likert's 5-point scale was used for data collection. Validity of the questionnaire was confirmed by 15 experts and professors and its reliability was obtained $\alpha=0.94$ by Cronbach's alpha coefficient. 84 questionnaires were handed out among all managers and directors of the studied sports clubs, 76 of which $(91.5 \%)$ was returned. The results showed that priority of CEOs roles, respectively, include decisional role $(4.16 \pm 0.61)$, informational role $(4.09 \pm 0.56)$, and interpersonal role $(4.03 \pm 0.67)$. The results of factor analysis also indicated that the roles of entrepreneurship, data collection, spokesman, and allocation of resources, respectively, are the most important roles of CEOs and negotiation, figurehead, and leadership roles are the least important ones in the desirable conditions. A significant difference was observed between the roles of managers in the current and desirable conditions (Sig.=0.001). The results suggested that the respondents' expectations of sports clubs CEOs' roles in desirable conditions is beyond their perceptions in the current situation. It can be generally concluded that sports clubs CEOs need to better perform all managerial roles, especially decisional role.
\end{abstract}

Key Words: Managerial Roles, Sports Club CEOs, Interpersonal Role.

Corresponding Author:

Mahboobeh Surani

E-mail: suranimahboob@yahoo.com 


\section{INTRODUCTION}

Mintzberg, in the late 1960s, defined role as a set of desired behaviors for a specific management (1). Roles are expected or predetermined behaviors that managers are expected to do them in different and specific circumstances (2). In some cases, managers delegate their roles to others. Mintzberg mentions 10 different but interconnected roles for managers in three categories of interpersonal, informational, and decisional. When managers play interpersonal and informational roles, they actually use their personal and communicative abilities. Interpersonal role include figurehead, leadership, and liaison roles. When managers do symbolic or ceremonial activities, they are performing their figurehead role and when they guide and motivate the subordinates, it is their leadership role. In liaison role, managers communicate with people outside the organization in order to acquire information, establish business relations, and monitor and track the facilities and other affairs. Informational role involves information collection, dissemination of information, and spokesman. In information collection and dissemination of information roles, managers track the information inside and outside the organization, collect the information, and share them with the subordinates at the appropriate time. As a spokesman, managers provide other individuals and external agencies with the required information. In decisional role, managers get use of their perceptual and decision-making skills. This role includes entrepreneur, detente, conflict handler, resources allocator, and negotiator. To make changes in their organizations, entrepreneur managers conduct research and surveys and apply new ideas and methods. Whenever an organization is faced with tension and unexpected problems, managers are responsible for providing solutions and corrective actions and, by playing the role of conflict handler, preventing crises and settling the problems. Also, in the role of resources allocator, managers are responsible for the proper allocation of resources. The last decisional role is negotiation role, in which managers play the role of the representative of their organization in negotiations and contract signing meetings $(1,3)$.

Generally, due to the diverse nature of sport management in various parts of the world, CEOs of sports clubs in our country are faced with unique and non-generalizable issues and problems. Sports clubs are not separated from economic, social, and political issues. Accordingly, objectives and orientations of sports clubs are completely different from those of other organizations and the CEOs, as the most influential person in a sports club, require to play different and special roles commensurate with their job and the changing environments inside and outside the clubs. Therefore, understanding the role of CEOs can be indicative of a sports club's and determination of the importance and priority of their roles and investigation of the gap between the current and desirable situation can provide a feedback for identifying the educational needs of sports clubs CEOs in order to develop and strengthen the management of professional sport.

Management of sports clubs is of special sensitivity due to interaction with government, private sector, sponsors, and sports federations. Job competency of managers involves three dimensions of tasks, roles, and skills. The proper playing of the managerial roles by the CEOs as the head of sports clubs is of great importance, as management style, activities, and personal behaviors of CEOs is a topic currently discussed in many sports circles and events. In most cases, following a good or bad sports result, long discussions take place about the role of effective or ineffective managers or management, the results of which mostly lead to taking wrong or right and successful or unsuccessful decisions, right or 
wrong decision-making, and even finding a manager guilty (4).

Managers with necessary competencies enjoy high skills and do their duties and responsibilities very well. Constant changes affecting the performance of professional sports clubs such as globalization process, privatization of clubs, governmental policies, professionalization of clubs, and technology development have forced sports clubs and their CEOs to act more professionally in doing their duties and playing their roles. Accordingly, understanding the roles of CEOs of sports clubs is of special importance, because misunderstanding of managerial roles can lead to a weak management and loss of resources in clubs. In other words, managers will not be able to perform their duties unless they are aware of their managerial roles (5).

Therefore, it is necessary to understand and identify the managerial roles of sports clubs CEOs and it could be effective in selection and appointment of qualified CEOs, performance evaluation, training, development, and improvement of management in sports clubs. Tsai (1995) studied the required competencies for recreational sports managers in universities of Greece and the US and concluded that the top ten competencies ranked by Greek managers include communication with the staff, facilities planning, indoor sports training ability, budget monitoring, control and allocation of resources, motivating the staff, budget preparation, communication with participants, and special planning, respectively, and the top ten competencies identified by the US sports administrators involve, respectively, communication with the staff, communication with participants, public relations, decision-making process, motivating the staff, addressing the complaints of participants, supervision on the staff and personnel, solving the problems, delegation of responsibilities, and time management (6). According to the findings of Danylchuk and Chelladurai (1999) and Horch and Schütte (2003), managers have to perform different roles in different fields $(7,8)$. In fact, all managers play all their managerial roles to some extent, but managers at various levels of management and as specialized managers need to perform a specific set of professional roles (8). Thus, CEOs in the head of sports clubs play roles commensurate with their managerial level which require to be more carefully surveyed.

Brophy and Kiely (2002) introduced interpersonal and communication roles as the main factors of managers (9). The results of a study conducted by Case and Branch (2003) also showed that the most important roles and competencies for the upper levels of management include budgeting, communication skills, understanding the priorities, ability to choose the subordinates, decision making, goal setting, problem solving, understanding the legal positions, and the skill of employees assessment (10). The findings of Horch and Schütte (2003) showed that competencies of CEOs of sports clubs and managers of federations in Germany are composed of various social and communicative aspects and the respondents emphasized on the importance of interpersonal roles and competencies like public relations, advertising, and individual management techniques. The most important roles in their study were reported to be information collection, liaison, conflict handler, and détente, respectively (8).

Nikoyan (2003) studied the effect of using computer on the way of practicing the management roles and the results indicated that managers who use computer more, compared with those who use less or never, are more successful in playing the roles of disseminator of information, information collection, and resources allocator and less successful in conflict handler role. Based on the theoretical discussions and findings of this study, skills and abilities are necessary for playing the job roles better and better (11). Pearson and Chatterjee (2003) acknowledged the importance of these roles and found that 
roles can be played differently depending on the level of individual skills (12). Literature argued that planning and allocation of resources are the most important duties of middle and lower level managers and showed that senior managers should pay a special attention to the external environment and carefully monitor it and focus on competitors, industry, policies, and society (13).

Connolly and McGing (2006) reported that conflict handling and decision-making are the most important job competencies of executives in housing industry in Ireland (14). Cieślińska (2007) studied the roles of commercial organizations managers and mentioned three sets of roles including priority of task and job (conservative and creative roles), conduct of business (strategic and organizing roles), and supervisory and monitoring roles (interpersonal, informational, and decisional roles). In this study it was found that the roles of leadership, information collection, distribution, entrepreneurship, conflict handling, and allocation of resources have greater impact on a company's internal context, and other roles (figurehead, liaison, spokesman, negotiation) are effective in the performance of both external and internal context of a company (15).

Gabor (2008) studied the importance of managerial duties and functions in agricultural economics organizations and stated that the most important roles of top managers include collection of information inside the organization, organizing, collection of information outside the organization, decision-making, control, planning, personnel management, training, and guidance and for middle managers involve decision-making, providing information inside the organization, training and guidance, control and planning, organizing, collection of information outside the organization, and personnel management, respectively.

Also, decision-making, collection of information inside the organization, organizing, training and guidance, planning and control, collection of information outside the organization, and personnel management, respectively, were introduced as the most important roles of lower level managers (16). Jeou-Shyan et al. (2011) studied the competencies of senior managers in the hotel industry in Taiwan and stated that the most important competencies belong to leadership, management of crises, and conflict handling roles (17).

Generally, it can be observed that managerial roles is one of the most important dimensions interested by researchers in studying the competencies of managers $(6,10$, 14, 17).

Ghourchian and Mahmoudi (2004) reported that the top priority roles of educational managers in guidance schools include entrepreneurship, crisis management, informational, decision-making, change management, and advisory and communicative roles (18). Doaei and Mortazavi (2006) have stressed the importance of interpersonal roles (19). The results of a study conducted by Bazyari and Amirtash (2006) showed that informational role is more important than decisional role for middle managers and interpersonal and communicative, informational, and decisional roles, respectively, are the top roles of operational managers (20). Niromand and Ranjbar (2010) showed that identifying and solving the problems, executive management, creative thinking, and decision-making, respectively, are the most important competencies of managers in the success of technology-based companies from the perspective of managers, inventors, and innovators (21). Esmaeili and Hosseini (2012) asserted that managers who have higher skills and abilities are able to better play the roles assigned to them (22). Ramezani et al. (2011) evaluated the performance of sports federations' managers using the roles proposed by Mintzberg and stated that the most important roles of top managers include allocation of resources, figurehead, leadership, 
and negotiation. They also mentioned that managers need to do the all ten managerial roles proposed by Mintzberg but allocation of resources is of higher importance (23).

Previous studies show that the roles of managers in different organizations may vary depending on the nature, mission, features, and programs of organizations. Additionally, no study had been conducted on determining the components of managerial roles of sports clubs CEOs in Iran. Hence, the author aims to take an effective step in determining the managerial roles of sports clubs CEOs by acquiring all of the components determining the managerial roles, setting the priority of these roles in the desirable condition, and comparing the current and desirable conditions. The present study also seeks to find answer to the following questions:

- What are the components and criteria related to the managerial roles of sports clubs CEOs?

- How is the priority of the studied roles in the desired condition?

- Is there any difference between the respondents' expectations of managerial roles of sports clubs CEOs (desirable condition) and their understanding of how to play these roles in the current condition?

Is there a negative gap between the mean of managerial roles in the current and desirable conditions?

\section{MATERIALS AND METHODS}

The present research is a descriptiveanalytic study.

Participants. Statistical population included all managers and directors of Sepahan, Zobahan, Foolad Mahan, and Gitipasand sports clubs $(\mathrm{N}=83)$, which was considered as the sample as well.

Tools. To determine the items of managerial roles, an initial questionnaire was prepared by reviewing the foundations and research tools in foreign papers such studies conducted by Horch and Schütte (2003) and Koenigsfeld et al. (2012) and acquiring the comments and opinions of exerts $(8,24)$. After modifying some items of initial questionnaire, a 31-item questionnaire (interpersonal with 11 items, informational with 9 items, and decisional with 11 items) on a Likert's 5-point scale (from very high to very low) was prepared.

Validity of the questionnaire was confirmed by 15 experts and professors and its reliability was obtained $\alpha=0.94$ by Cronbach's alpha coefficient. 84 questionnaires were handed out among all managers and directors of the studied sports clubs, 76 of them $(91.5 \%)$ was returned.

Statistical Analysis. Confirmatory factor analysis and structural equation modeling in Amos 16 software were used for confirming the construct validity of this questionnaire and data analysis. Also, to determine the priority of roles, repeated measures and Bonferroni post hoc test were applied. The dependent t-test was used to describe data (mean and standard deviation) and compare the role in the current and desired conditions. Recent statistical analyses were performed using Statistical Package for Social Sciences (SPSS) software. Significance levels accepted at $\mathrm{p}<0.05$

\section{RESULTS}

Descriptive analysis of findings show that mean age and mean years of service of respondents are equal to 34.72 and 6.38 , respectively. $77.6 \%$ of the respondents was male and $22.4 \%$ of them was female. $52.6 \%$ of the respondents had bachelor's degree, $9.2 \%$ and $2.6 \%$ of them had master's and $\mathrm{PhD}$ degree, respectively.

All items related to all roles of desirable condition in the confirmatory factor analysis are significant at a significance level of 0.001 . This significance of regression weights indicate the convergent validity of the variables in the model (Table 1). 
Table 1. Results of confirmatory factor analysis of research model for the desirable conditions

\begin{tabular}{ccccccc}
\hline P & C.R. & S.E. & Estimate & Roles & & \\
\hline & & & 1.000 & Liaison & $<---$ & Interpersonal \\
$* * *$ & 6.609 & 0.131 & 0.866 & Leadership & $<---$ & Interpersonal \\
$* * *$ & 9.005 & 0.113 & 1.020 & Figurehead & $<---$ & Interpersonal \\
& & & 1.000 & Spokesman & $<---$ & Informational \\
$* * *$ & 7.237 & 0.111 & 0.802 & Disseminator of information & $<---$ & Informational \\
$* * *$ & 8.739 & 0.128 & 1.117 & Information collection & $<---$ & Informational \\
$* * *$ & 7.270 & 0.172 & 1.251 & Allocation of resources & $<---$ & Decisional \\
$* * *$ & 6.561 & 0.163 & 1.071 & Conflict handler & $<---$ & Decisional \\
$* * *$ & 6.358 & 0.210 & 1.336 & Entrepreneurship & $<---$ & Decisional \\
& & & 1.000 & Negotiation & $<---$ & Decisional \\
\hline
\end{tabular}

Entrepreneurship (0.876), information collection (0.853), and spokesman (0.843), respectively, are the most important factors of managerial roles in the desirable conditions. In addition, entrepreneurship, information collection, and liaison with a factor load of $0.876,0.853$, and 0.739 , respectively, are the most important factors in decisional, informational, and interpersonal roles. According to the factor loads of ten managerial roles in the research model, entrepreneurship, information collection, spokesman, and allocation of resources have the highest priority and importance and negotiation, figurehead, and leadership have the least priority and importance. Measurement model presented in Figure 1 indicate high interaction between three types of managerial roles and shows the factor load of each of the items of the questionnaire (Table 2).

\begin{tabular}{|c|c|c|c|c|}
\hline Priority & Factor load & Roles & & \\
\hline 7 & 0.739 & Liaison & $<<--$ & Interpersonal \\
\hline 8 & 0.711 & Leadership & $<---$ & Interpersonal \\
\hline 10 & 0.680 & Figurehead & $<---$ & Interpersonal \\
\hline 3 & 0.843 & Spokesman & $<---$ & Informational \\
\hline 6 & 0.743 & Disseminator of information & $<---$ & Informational \\
\hline 2 & 0.853 & Information collection & $<---$ & Informational \\
\hline 4 & 0.837 & Allocation of resources & $<---$ & Decisional \\
\hline 5 & 0.759 & Conflict handler & $<---$ & Decisional \\
\hline 1 & 0.876 & Entrepreneurship & $<---$ & Decisional \\
\hline 9 & 0.705 & Negotiation & $<---$ & Decisional \\
\hline
\end{tabular}

Acceptable models have a RMSEA equal to or less than 0.05. According to Table 4, the RMSEA value obtained for the present study model is equal to 0.05 , so this model is acceptable in terms of this index. Values of 2 to 3 are mostly considered acceptable for CMIN/DF index. As above table shows, the value obtained for the research model in this study is acceptable. About other fitness indices, the closer to 1, the more acceptable they are. Goodness of fitness, according to Table 4, shows that the final research model has a very high fitness (table 3). 
Table 3. The output parameters of the confirmatory factor model

\begin{tabular}{cccccccc}
\hline RMSEA & CFI & IFI Delta2 & GFI & CMIN/DF & DF & CMIN & \\
\hline 0.050 & 0.989 & 0.990 & 0.919 & 1.186 & 29 & 34.382 & Roles \\
\hline
\end{tabular}

Sphericity Assumed test was used to examine the differences between the data. The results of Table 5 suggest that there is a significant difference priority of managerial roles (Table 4).

\begin{tabular}{|c|c|c|c|c|c|c|}
\hline \multicolumn{3}{|c|}{ Mauchly's test of sphericity } & \multicolumn{4}{|c|}{ Mutual effects of factors } \\
\hline Sig & $\left(X^{2}\right)$ & (W)Mauchly & Sig & $\bar{F}$ & Mean squares & df \\
\hline 0.28 & 2.5 & 0.967 & 0.04 & 3.21 & 0.332 & 2 \\
\hline
\end{tabular}

The results of Bonferroni test show that there is a significance difference between interpersonal and decisional roles and decisional, informational, and interpersonal roles, respectively, have the highest priority in managerial roles (Table 5).

Table 5. Results of Bonferroni test for paired comparison of managerial roles of sports clubs CEOs in the desirable condition

\begin{tabular}{ccc|cccc}
\hline \multicolumn{2}{c|}{$\begin{array}{c}\text { Comparison of mean values of roles and } \\
\text { determining the priorities }\end{array}$} & \multicolumn{2}{c}{ Paired comparison of managerial roles of sports clubs CEOs } \\
\hline Priority & $\begin{array}{c}\text { Mean } \pm \text { standard } \\
\text { deviation }\end{array}$ & Roles & $\begin{array}{c}\text { Level of } \\
\text { significance }\end{array}$ & $\begin{array}{c}\text { Mean } \\
\text { difference }\end{array}$ & Roles \\
& $4.03 \pm 0.67$ & Interpersonal & 0.05 & 0.132 & Decisional & Interpersonal \\
\hline 3 & $4.16 \pm 0.61$ & Decisional & 0.80 & 0.061 & Informational & \\
2 & $4.09 \pm 0.56$ & Informational & 0.40 & 0.07 & Informational & Decisional \\
\hline
\end{tabular}

According to the obtained mean values, decisional (4.16 \pm 0.61$)$, informational (4.09 $\pm 0.56)$, and interpersonal $(4.03 \pm 0.67)$ roles, respectively, are the most important roles of managers in desirable condition. Table 7 shows that there is a significant difference between managerial roles in the current and desirable conditions (Sig. $=0.001)$ and also there is a negative gap between all roles in the current and desirable conditions. However, decisional role exhibit the highest negative gap (Table 6).

Table 6. Results of dependent t-test for studying the difference between the current and desirable conditions

\begin{tabular}{|c|c|c|c|c|c|c|}
\hline $\begin{array}{c}\text { Gap (difference } \\
\text { between mean values) }\end{array}$ & Sig & df & $\mathrm{t}$ & $\begin{array}{c}\text { Standard } \\
\text { Deviation }\end{array}$ & Mean & Pairs \\
\hline \multirow{2}{*}{-0.32} & \multirow{2}{*}{0.001} & \multirow{2}{*}{75} & \multirow{2}{*}{3.61} & 0.73 & 3.71 & Interpersonal (current condition) \\
\hline & & & & 0.67 & 4.03 & Interpersonal (desirable condition) \\
\hline \multirow{2}{*}{-0.35} & \multirow{2}{*}{0.001} & \multirow{2}{*}{75} & \multirow{2}{*}{4.61} & 0.68 & 3.73 & Informational (current condition) \\
\hline & & & & 0.56 & 4.09 & Informational (desirable condition) \\
\hline \multirow{2}{*}{-0.51} & \multirow{2}{*}{0.001} & \multirow{2}{*}{75} & - & 0.94 & 3.65 & Decisional (current condition) \\
\hline & & & 4.33 & 0.61 & 4.16 & Decisional (desirable condition) \\
\hline
\end{tabular}




\section{DISCUSSION AND CONCLUSION}

The results of the present study show that decisional, informational, and interpersonal roles, respectively, are the priorities for managerial roles and decisional role was identified as the most important one. Hence, sports actions in sports clubs management require competent CEOs who have learned correct decision-making in the context of sport as a powerful social institution (2). This is consistent with the findings of Case and Branch (2003), Connolly and McGing (2006), and Niroomand and Ranjbar (2010), because they have stated that decision-making is one of the most important job competencies of managers of sports facilities, housing industry, and technology-based companies $(10,14,21)$. The highest negative gap $(-0.51)$ was observed in decisional role which indicates that the respondents believe that the CEOs do not have the required ability in decisional role, while the CEOs of sports clubs can play an important and decisive role in the success or failure of their clubs in dealing with organizational issues and problems (25). They would take many wise small and big decisions which are based on management principles and deep understanding of specific aspects of sport (2).

The present study stresses the importance of decision-making for managers. Tsai (1995) states that decision-making is one of the most important competencies of sports managers in the US (6), and Gabor (2008) believes that this is the top role of middle and low level managers (16). Those who are active in sports management should give a special value and importance to decision-making process in training programs, so that more efficient managers will be educated and trained who can take better and wiser decision in relation to sport (2). In decisional role, entrepreneurship and allocation of resources obtained higher factor load and importance, while conflict handler and negotiation were least important. Hence, according to the research items, using the various methods of gaining revenue, offering new ideas in entrepreneurship role, and proper distribution of funds can be the most important measures done by the CEOs for the development of entrepreneurship and improvement of resources allocation. These results are consistent with the findings of Shapira and Dunbar (1980) and Ghourchian and Mahmoudi (2004), because they have stated that entrepreneurship is one of the most important roles of managers $(18,26)$. In addition to entrepreneurship, Shapira and Dunbar (1980) emphasized on the importance negotiation role which is inconsistent with the results of the present study, because negotiation, with a factor load of 0.705 , had the least importance from the perspective of respondents. Also, conflict handler is less important than entrepreneurship and allocation of resources. This discrepancy could be due to the different organizations and populations studied in different studies. In the items of the present study, doing corrective measures in the face of unexpected situations and quick decision-making indicate the importance of ability of sports clubs CEOs for addressing the problems. In the studies conducted by Tsai (1995) and Case and Branch (2003), different results were obtained, because they believe that addressing the problems is one of the most important roles of sports managers $(6,10)$. Jeou-Shyan et al. (2011), Connolly and McGing (2006), and Niroomand and Ranjbar (2010) stated that conflict handler and crisis management are the most important competencies in managers of hotel industry, housing industry, and technology-based companies $(14,17,21)$. Therefore, it seems that paying attention to this issue by the CEOs and effective and appropriate management of conflicts and small problems can be the best way to prevent big problems and conflicts in sports clubs (3). Managers requires more knowledge and effort for playing this managerial role.

According to the results, informational role is the second priority and less important than decisional role. This result can be due to the study of high levels of sports clubs 
management. There are different results in low levels of management, as Bazyari and Amirtash (2006) reported that information role is more important than decisional role for middle and operational managers (20).

Sports clubs manager need to play informational role in order to act successfully in regular holding of board of directors meetings and communication with the members. The model presented in this study show that information collection, with a factor load of 0.853, has the highest importance among the informational roles. This is consistent with the findings of Gabor (2008) and Kraut et al. (1989) who argued that managers should pay a special attention to the external environment and carefully monitor it and focus on competitors, industry, policies, and society in order to collect the required information (13, 16). By contrast, Shapira and Dunbar (1980) asserted that collection of information, dissemination of information, and spokesman are have least importance and priority in managerial roles (26). The results of this study revealed a negative gap between the current and desirable conditions in informational roles. This shows that the CEOs of the studied sports clubs do not perform successfully in their informational roles such as regular holding of board of directors meetings and communication with the members and they need to improve their performance in this regard.

From the perspective of the respondent managers and directors, interpersonal roles have the least importance among the managerial roles. This result is inconsistent with the findings of Brophy and Kiely (2002), Horch and Schütte (2003), and Doaei and Mortazavi (2005) who mentioned that interpersonal role is one of the most important competencies of managers $(8,9,19)$. The managers and directors participated in this study believed that interpersonal roles establishing effective relationships with individuals outside the club, welcoming and escorting the gusts and officials at events and meetings, and ceremonial are less important in managerial roles. In contrast, Kim (1997) introduces interpersonal and communicative roles as the most important competencies of managers (27), and Doaei \& Mortazavi (2006) believe that paying a special attention to interpersonal roles is of great importance (19), otherwise management efficiency will decline. Today, there is much evidence that some sports organizations and clubs are facing with problems because of neglecting the issues such as establishing effective relationships with individuals outside the club, effective communication with the public relations of the club, the media, and international organizations, and attending the special ceremonies for players, club members, and sports organizations. As a negative gap was found between the current and desirable conditions in informational role in the present study, since the CEOs usually are tackling major planning and taking more important decisions, they do not have enough time for interpersonal roles sometimes delegate them to others.

According to the findings of the present study, entrepreneurship, information collection, spokesman, and allocation of resources are the most important managerial roles of sports clubs CEOs and negotiation, figurehead, and leadership are the least important ones. This is inconsistent with the findings of Ramezani, Khabiri, and Alvani (2011) and Shapira and Dunbar (1980) (23, 26). Jeou-Shyan et al. (2011) have mentioned the importance of leadership (17), and Kim (1997) states that leadership and negotiation, respectively, are the most and least important roles in determining the competency of managers (27). Thus, CEOs should try to efficiently and successfully play the most important roles in the model of managerial roles proposed in the present study (entrepreneurship, information collection, spokesman, and allocation of resources). According to the priority of roles, managers should give a special importance to their ability for decision-making, because the consequences 
of decisions play a decisive role in achieving the objectives a sports club.

High interaction between three types of managerial roles indicates the strong relationship between them. This means that when managers have a high ability in playing one of these roles, they can act more effectively and more successfully in other roles. Generally, the first priority of decisional role in the desirable condition indicates the high importance of this role for sports clubs CEOs and the significant negative gap between the current and desirable conditions necessitates the full understanding of important roles of decision-making such as entrepreneurship and allocation of resources. In addition, plans that are performed in order to develop and improve decisional roles, due the close interaction of decisional and interpersonal roles, can be effective and useful in improving the performance of managers in playing interpersonal roles. As a negative gap was observed between the current and desirable condition in three types of managerial roles in this study, it can be concluded that sports clubs CEOs needs to improve their performance in playing all of them. Ramezani, Khabiri, and Alvani (2011) stated that managers need all ten managerial roles, but allocation of resources is more important (23). According to the findings of the present study, CEOs of the studied sports clubs need to improve all managerial roles, especially decisional role. Since the expectations of sports clubs managers' roles in desirable conditions is beyond their perceptions in the current situation, it is necessary that CEOs of these sports clubs to pay a special attention to more understanding of managerial roles and decreasing the existing gap in order to achieve a better performance in playing the managerial roles.

\section{REFFRENCES}

1. Nasehifard V, Saadat MR, Masomzadeh A. Evaluation Pattern for Merits and Competences of the Ministry of Commerce Managers. Commercial Surveys. 2010;8(41):3-18 [Article in Farsi].

2. Pedersen PM, Parks J, Quarterman J, Thibault L. Contemporary Sport Management: Human Kinetics; 2011. 461 p.

3. Lussier RN, Kimball DC. Sport Management: Principles, Applications, Skill Development: Thomson/SouthWestern; 2004. 459 p.

4. Majdara A. Comprehensive Guide to Sports Management. Tehran, Iran: Avay-e-Zohour Publication; 2011 [Book in Farsi].

5. Duygulu E, Ciraklar N. Team effectiveness and leadership roles. 20087245.

6. Tsai C-C. A comparative analysis of the competencies of collegiate recreational sports directors in the United States and the Republic of China [Ph.D.]. Ann Arbor: University of Minnesota; 1995.

7. Danylchuk KE, Chelladurai P. The nature of managerial work in Canadian intercollegiate athletics. Journal of Sport Management. 1999;13(2):148-66.

8. Horch H-D, Schütte N. Competencies of sport managers in German sport clubs and sport federations. Managing Leisure. 2003;8(2):70-84.

9. Brophy M, Kiely T. Competencies: a new sector. Journal of European Industrial Training. 2002;26(2/3/4):165-76.

10. Case R, Branch J. A study to examine the job competencies of sport facility managers. International Sports Journal. $2003 ; 7(2): 25-38$.

11. Nikoyan H. The Effect of Computer Use on Applying Managerial Roles in National Compony of Iran Copper Industry Kerman, Iran: Kerman Branch, Islamic Azad University; 2003 [Thesis in Farsi].

12. Pearson CAL, Chatterjee SR. Managerial work roles in Asia: An empirical study of Mintzberg's role formulation in four Asian countries. Journal of Management Development. 2003;22(8):694-707.

13. Kraut AI, Pedigo PR, McKenna DD, Dunnette MD. The role of the manager: What's really important in different management jobs. The Academy of Management Executive. 1989;3(4):286-93.

14. Connolly P, McGing G. Graduate education and hospitality management in Ireland. International Journal of Contemporary Hospitality Management. 2006;18(1):50-9.

15. Cieślińska K. The Basic Roles of Manager in Business Organization. Roczniki Akademii Rolniczej w Poznaniu. 2007;CCCLXXXV, Ekon. 6:3-12. 
16. Gabor S. A Study of management tasks \& functions in Argoeconomic organizations. Hungary: University of Debrecen; 2008.

17. Jeou-Shyan H, Hsuan H, Chih-Hsing L, Lin L, Chang-Yen T. Competency analysis of top managers in the Taiwanese hotel industry. International Journal of Hospitality Management. 2011;30(4):1044-54.

18. Ghourchian NG, Mahmoudi AH. Collection of Performance Standards of Educational Principals and Rendering Suitable Model. Journal of Educational Innovations. 2004;3(8):107-32 [Article in Farsi].

19. Doaei H, Mortazavi S. Management Skills. First ed. Mashhad, Iran.: Bayan-e-Hedayat-e-Noor Publication; 2006 [Book in Farsi].

20. Bazyari EAZ, Amirtash AM. Managers, Employing on the Bases of Meritocracy in Physical Education Organization. Journal of Movement Science \& Sports. 2006;4(7):1-10 [Article in Farsi].

21. Niroomand P, Ranjbar M, editors. The role of competence and skills training on development of technology capabilities in technology-based companies. 4th National Congress of Iranian Technological Management; 2010; Tehran, Iran: Iranian Association for Management of Technology.

22. Esmaeili B, Hosseini H. A Study of the Relationship of Skills and Abilities to Managerial Roles. Quarterly Journal of New Approach in Educational Administration. 2012;3(1):101-16 [Article in Farsi].

23. Ramezani ZN, Khabiri M, Alvani SM, Tondnevis F. Use of Mintzberg's Model of Managerial Roles to Evaluate Sports Federations Managers of Iran. Middle-East Journal of Scientific Research. 2011;10(5):559-64.

24. Koenigsfeld JP, Kim S, Cha J, Perdue J, Cichy RF. Developing a competency model for private club managers. International Journal of Hospitality Management. 2012;31(3):633-41.

25. Rappe C, Zwick T. Developing leadership competence of production unit managers. Journal of Management Development. 2007;26(4):312-30.

26. Shapira Z, Dunbar RL. Testing Mintzberg's managerial roles classification using an in-basket simulation. Journal of Applied Psychology. 1980;65(1):87-95.

27. Kim HS. Sport management competencies for sport centers in the Republic of Korea [Ed.D.]. Ann Arbor: United States Sports Academy; 1997. 
تازههاى علوم كاربردى ورزش

مقاله اصيل

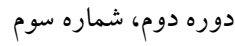

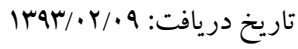

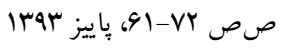

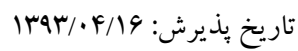

\title{
بروسى نقشى هاى مديريتى مديران باشَاههاى ورزشى در وضعيت مطلوب و موجود
}

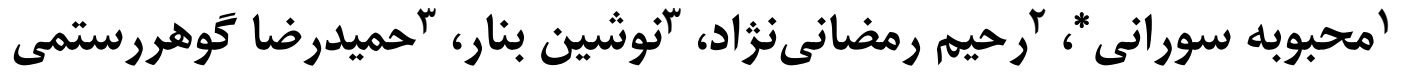

\author{
ا. كارشناسى ارشد مديريت ورزشى، دانشكده تربيتبدنى و علوم ورزشى، دانشخاه كَيلان، رشت، ايران.

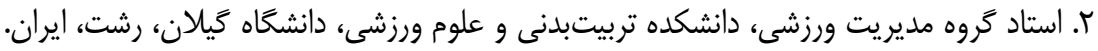

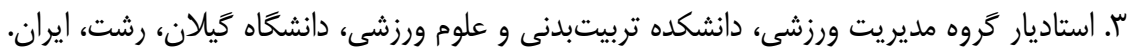

امروزه ايفاى صحيح نقشهاى مديريتى مديران در مديريت اثربخش و موفق باشكاههاى ورزشى اهميت ويزهاى دارد. هدف از اين يثوهش

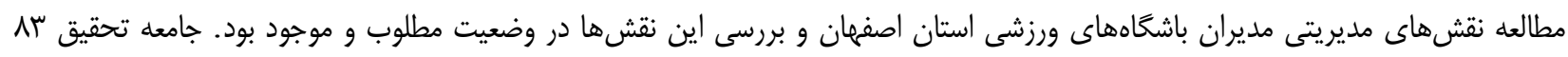

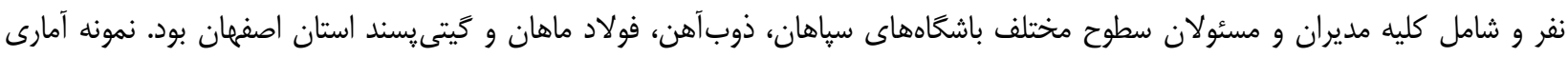

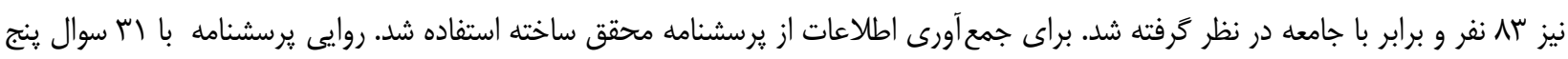

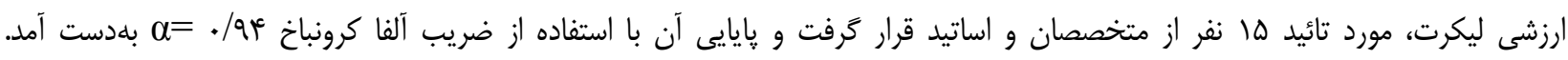

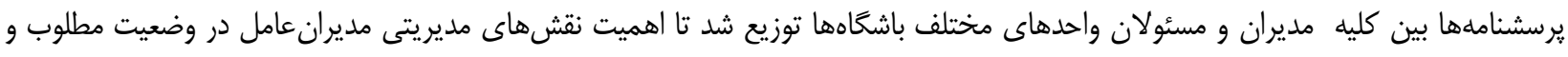

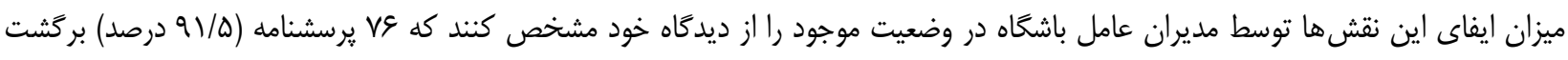

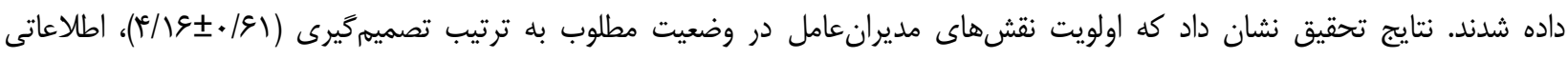

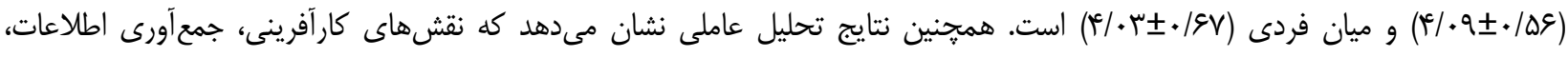

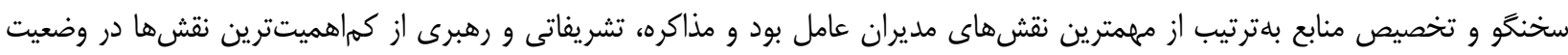

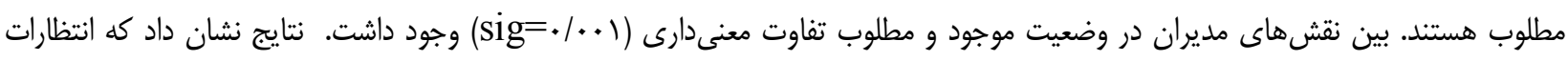

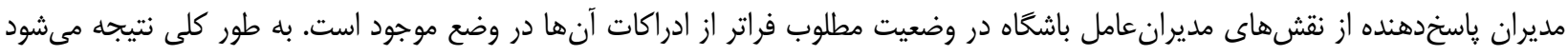

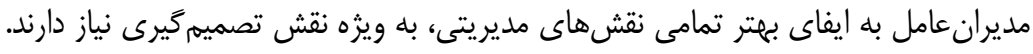

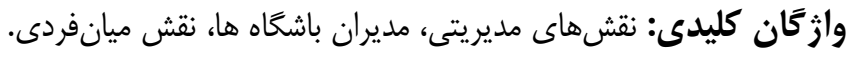

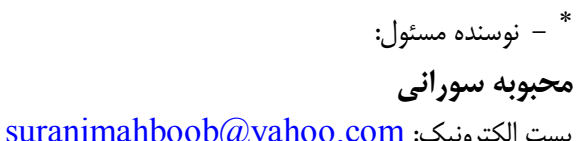

